\title{
Paul Langevin (1872-1946)
}

\section{From Montmartre to the Panthéon: The Paris journey of an exceptional phussicist}

\author{
Julien Bok and Catherine Kounelis
}

Ecole Supérieure de Physique et Chimie Industrielle de Paris • France

DOI: 10.1051/epn:2007001

$\mathrm{P}_{\mathrm{t} \text { tis }}$ aul Langevin has been an emblematic figure in the first half of the $20^{\text {th }}$ century. He has been a principal player in all the major scientific revolutions of his time: Relativity, Quantum Mechanics and Statistical Physics. He has invented "Sonar", the system of underwater detection using ultrasonic echography, so important now for medical imaging.

He has also involved himself in the social and political causes of his age: human rights, pacifism, the fight against the rise of fascism and Nazism in Europe. He has been in 1923 among those walking for Peace, with Einstein, in the streets of Berlin.

He believed in the power of Science and Reason to bring more justice and happiness into the life of man. For him education, and particularly science teaching, was the best means to reach this goal.

\section{Biography}

'I grew up, after the 1870 war, between a republican father and a mother devoted in her sacrifice. They had witnessed the Paris siege and the bloody repression of the Commune. Through their accounts, they developed in my heart the horror of violence and the passionate desire for social justice' (Paul Langevin).

Paul Langevin was born in Montmartre, at the "Bateau Lavoir", on January the $23^{\text {rd }}, 1872$. After the Lavoisier School, he studied at the "Ecole de Physique et Chimie Industrielles (ESPCI), of the city of Paris" (1889-1891) then at "Ecole Normale Supérieure" (1894-1897).

In 1898-99, he stayed for some time in the Cambridge laboratory of J. J. Thomson at a time when the latter was working his way to the discovery of the electron. In 1902, he defended his PhD thesis on ionized gases, a subject on which he had started to work in Cambridge. A few weeks later, he was called to act as a substitute for Eleuthère Mascart for his lectures in physics at the Collège de France. It was an exceptional start to his career, even for that time and would be quite impossible now, which placed him, at thirty, among the most eminent members of the scientific community in Paris.

In 1905, he became Professor of Physics at ESPCI, at which he was later Director of Studies for 16 years (1909-1925). In 1909, he

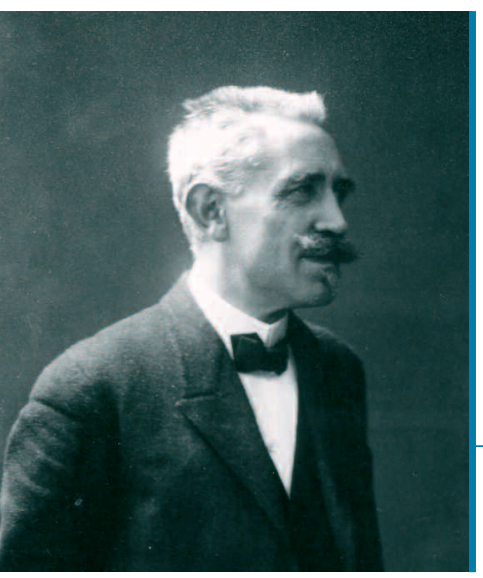
was appointed to the prestigious position of titular Professor at the "Collège de France". He participated actively in the Solvay Physics meetings from their first in 1911, was elected as a member of its scientific committee in 1921 then as President in 1927, in succession to Lorentz. He was elected to the French Academy of Sciences in 1934.

4 Fig. 1: "Paul Langevin" in Paris (1922) photographed by Henri Manuel. (c) ESPCI-CRH.
On 30 October 1940, Langevin was arrested at the ESPCI by the Germans and put in jail for a few weeks before being placed under house arrest in Troyes. He escaped to Switzerland in May 1944 under the identity of LéonPhilippe Pinel, thanks to a false ID card procured by Frédéric Joliot-Curie.

After the "Liberation", he returned to his activities at ESPCI and at the Collège de France. He became President of the French "Ligue des Droits de l'Homme" (Human

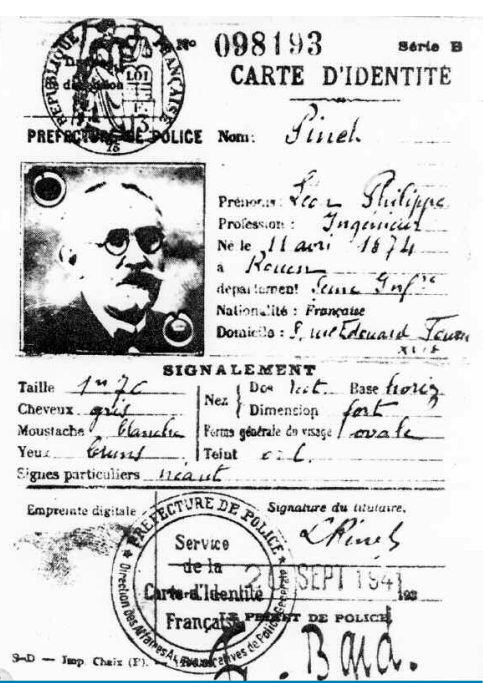

A Fig. 2: "False ID card with which Langevin escaped to Switzerland in 1944" (c) ESPCI-CRH.
Rights League), succeeding Victor Basch, and a member of the atomic energy committee of the Academy of Sciences, together with Frédéric Joliot-Curie and Louis de Broglie, in 1945. The next year, he became an assistant delegate for France at UNESCO.

Paul Langevin died on October the $30^{\text {th }}, 1946$. National funerals were celebrated on 19 December 1948 when the ashes of Paul Langevin and Jean Perrin were transferred to the Panthéon, in Paris.

\section{Scientific work}

The scientific work of Paul Langevin is very rich and covers several domains in Physics.

\section{Magnetism}

The thesis of Pierre Curie (1895) reported on an experimental study of the magnetic properties of matter in which he gave his famous law: the magnetic susceptibility of paramagnetic materials varies as $1 / \mathrm{T}$, where $\mathrm{T}$ is the absolute temperature. Langevin gave a theoretical explanation, assuming that each atom or molecule carries a magnetic moment and that the magnetization comes from a competition between the action of the magnetic field and the random thermal motion. Using Boltzmann's factor, $\exp (-E / k T)$, he found easily the $1 / \mathrm{T}$ law (1905). He assigned the magnetic moment to the electrons orbiting locally around the atoms or molecules. He did not quantify the magnetic moment (the spin was not yet known), but his demonstration remains valid for the 1/T law, since it comes only from the Boltzmann factor. His results were immediately used by Pierre Weiss (1906), who introduced a molecular field to describe the interaction of the magnetic moments following Langevin's model, so explaining ferromagnetism. 


\section{Relativity}

According to his assistant, Edmond Bauer, Langevin had the idea to associate a mass (inertial) to the energy of photons or electrons as early as 1904. He suggested that the mass should be equal to $\mathrm{E} / \mathrm{c}^{2}$. He never published this formula and fully recognized Einstein's priority in the proper formulation of the special theory of relativity. He had been immediately enthusiastic about this theory and acted strongly to make it accepted and taught by French physicists. As early as 1910-11, he devoted his lecture course at the Collège de France to it. He gave many lectures on the subject and proposed the famous paradox of the travelling twins to illustrate the notion of time dilation. He invited Einstein to lecture at the Collège de France just after the first World War, at a moment when the contact between French and German scientists was difficult. Albert Einstein was finally able to come in 1922 and his lectures have had an immense impact. An experiment to illustrate the paradox of the travellers has been conducted by the US Navy in 1971, using two twin atomic clocks. However its interpretation is not simple because one has to take into account the acceleration to which the travelling clock is submitted, inducing a slight delay. Langevin and Einstein remained very good friends all his life. Here is what Einstein wrote in a homage to Langevin published in "La Pensée" in 1947: 'It seems to me certain that he would have developed the special theory of relativity if it had not be done elsewhere; he had already recognized clearly its main points'.

\section{Brownian motion}

The study of Brownian motion, the movement of colloidal particles in suspension in a liquid, has been of great importance in physics. It is a proof of the thermal motion of a liquid on the molecule scale. Einstein gave a first theory of the effect (1905) with his famous formula relating the diffusion constant $\mathrm{D}$ to the viscosity constant $\mathrm{k}$. Einstein's approach was macroscopic and used thermodynamics. Langevin (1908) proposed a new approach. He followed the motion of one particle and accounted for the molecular collisions by a random force. This "Langevin's equation" has proved its particular usefulness in the study of the molecular fluctuations of numerous systems, including non-equilibrium thermodynamics. It is still used by biophysicists to study biological fluids which contain many particles in suspension.

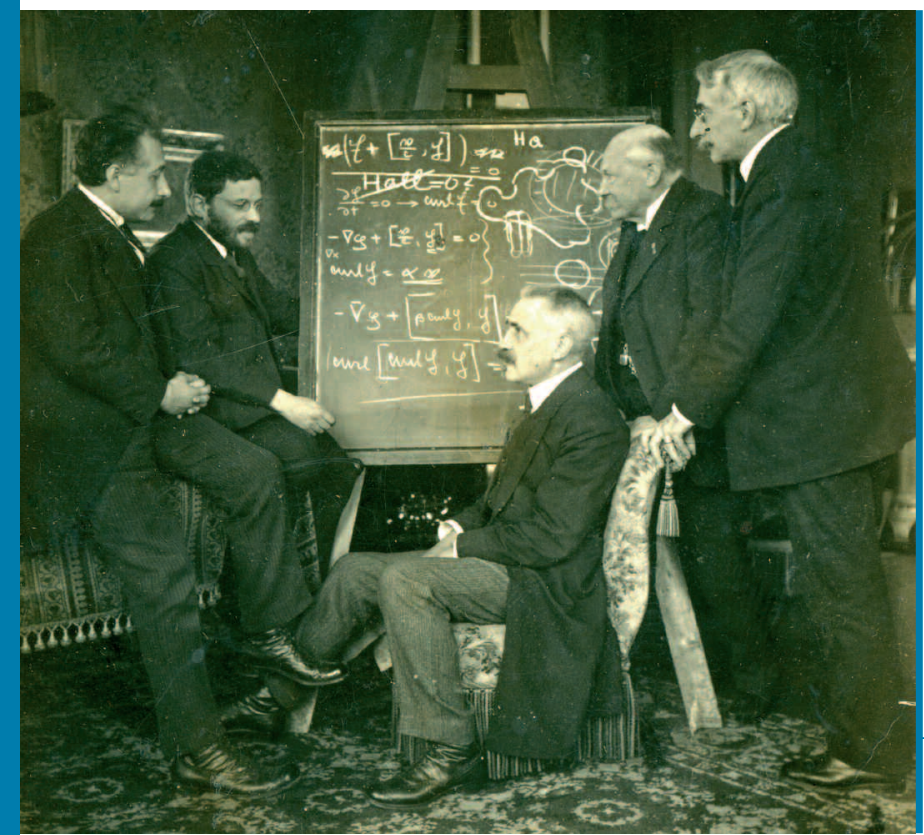

Ultrasonic echography

During the $1^{\text {st }}$ World War, Langevin, working with an engineer named Chilowski, put together the "Sonar", to be used to detect submarines through their reflection of ultrasonic waves. The invention benefitted from the studies of Pierre and Jacques Curie on piezoelectricity. Piezoelectric quartz crystals had been shown to be excellent ultrasound emitters and detectors. Their first transducer, the Florisson-Langevin probe, was a mosaic of quartz plates glued between two steel foils. It can be seen working in the Space of Science of ESPCI in Paris, among several other experiments on ultrasound. The technique of ultrasonic echography is now very commonly used in medical imaging and Langevin is universally recognized as its inventor.

As a physicist, he played a fundamental role in the diffusion of knowledge among scientists, the Solvay meetings being the best example. Through his teaching and lectures at the Collège de France, he exerted a strong influence among his colleagues and students: Henri Abraham, Edmond Bauer, Marcel Tournier, Fernand Holweck, Jean Saphores and later, Jacques Salomon, Frédéric Joliot, Léon Brillouin and Francis Perrin.

\section{The committed person}

The commitment of Langevin started with the Dreyfus affair. When a student in Cambridge he received a letter from Charles Péguy in 1898, which persuaded him to add his signature to the immense number of others on the famous petition in favour of Dreyfus. In 1899 he asks for admission in the French "Ligue des Droits de l'Homme". From the end of the First World War to the start of the Second, his commitment to human rights increased dramatically. He supported the strike of the railroad workers, the revolt of the Black Sea sailors and involved himself in the "League of Nations". As an active pacifist, he fought against nationalism, and worked for international scientific cooperation. In 1923, one year after Einstein's visit to Paris, he walked with him in Berlin in a demonstration for human rights. By now a member of the central committee of the French "Ligue de Droits de l'Homme", he became its vice-president in 1927.

The rise of the fascist movement in the thirties reinforced his militant activity. With Henri Barbusse and Romain Rolland, he joined the French section of the World Committee against War and Fascism and became its President in 1935. On 12 February 1934, he participated, with Victor Basch, President of the "Ligue des Droits de l'Homme", in the huge demonstration in Paris and on the $5 \mathrm{March}$, he was one of the three signatories of the text founding the Committee of Vigilance of Antifascists Intellectuals (CVIA), with the ethnologist Paul Rivet and the philosopher Alain. The recipient of mass popular support, he chaired the meeting of leftist organisations on 8 June 1935 to prepare a large demonstration for the occasion of the next $14^{\text {th }}$ July. Although a pacifist, Langevin renounced a blind and absolute pacifism, favouring a firm attitude towards Hitler. A vote on this being against him, he resigned from CVIA in May 1936. With Victor Basch, he chaired the committee in favour of republican Spain and went to London to meet W. Churchill and many other Parliament members, to try to convince them of the risks of non-intervention. While close to the communist party but not yet a member (he became one in 1944) and a founder of the Circle of the new Russia, he nevertheless condemned in 1939 the German-Soviet pact, in accord with other French scientists

4 Fig. 3: Left to right: A. Einstein, P. Ehrenfest, P. Langevin, H. Kammerlingh Onnes and P. Weiss in 1920. (C) ESPCI-CRH. 
(F. and I. Joliot-Curie, Henri Laugier, Aimé Cotton). With Norman Angell, a recipient of the Nobel Peace Prize, he co- directed the journal "Clarté" and, in 1939, he founded "La Pensée", a "journal of modern rationalism", with Georges Cogniot and Georges Politzer.

\section{Science and education}

To Langevin, science, education and political action belonged to the same commitment. As early as 1904, he showed his interest towards the questions of education and scientific learning, giving lectures on the subject. Throughout his life and particularly after 1930, he insisted on the 'human value of science', the 'social role of the learned' or 'science as a factor of moral and social evolution', 'science and liberty', 'science and peace', 'thought and action'. He was President of the French Society of Pedagogy (1922), a member of the reform committee of the "Ecole Unique" (1925) and President of the "Union Rationaliste". He gave many talks, opened up science to the general public, and created the workers University (1932). He even involved himself in the new development of the time, that of radio communication, as, for example, a member of the advisory group on radio programmes and broadcasting and as chairman of the administrative council of "Radio Liberté, with Léon Blum and Paul Vaillant-Couturier. In 1931, he went to China, as a member of an international committee of the "League of Nations", to make proposals for the reform of the Chinese educational system.
After the Second World War, he chaired the Commission on the reform of the French educational system. The report "Langevin-Wallon" was submitted to the government on June $17^{\text {th }}, 1947$ by the psychologist Henri Wallon who had succeeded in the chair following the death of Langevin at the end of 1946. This report has strongly influenced the post-war reforms of the French educational system.

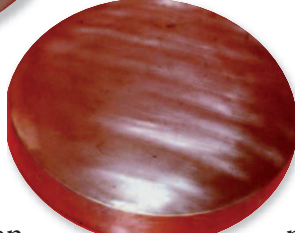

\section{About the Authors}

Julien Bok, professor emeritus at the University of Paris VI. Former director of the Solid State Physics laboratory of Ecole Normale Supérieure and later of the Solid State Physics Laboratory of ESPCI. His main contributions are in the field of transtport properties of semiconductors and theory of superconductivity. Catherine Kounelis is currently the head of the Library and of the Scientific Archives Center of the ESPCI. She organised recently an exhibition of Langevin's drafts and photographs and co-authored La Physique de Paul Langevin. Un savoir partagé with M.-C. Bustamante. Her main research interest is in the history of science with emphasis on $19^{\text {th }}$ - and $20^{\text {th }}$ - century chemistry and physics.

This article as been published in French by the French Physical Society in it's bulletin: Reflet de la Physique, 1, 14 (2006)

$\Delta$ Fig. 4: The Florisson-Langevin probe. It was made of a mosaic of single crystal quartz plates glued between two steel foils. The plate thickness is calculated to give a resonance at 1.3 MHertz. ( ) ESPCI and French Navy. 